\title{
ACADEMIC UNDERGROUND
}

(A study of Biro Bimbingan Skripsi (BBS)/ Thesis writing advice bureau in Daerah Istimewa Yogyakarta)

\author{
By: Hujair AH. Sanaky*
}

\begin{abstract}
:
The current research analyzes the background of the emergence of a non-official Biro Bimbingan Skripsi (BBS)/ Thesis Writing Advice Bureau. The research maps the patterns of the services, and recognizes the characteristics of students who use this service. This research used dependent variable, independent variable, and moderating variable. Data were gathered through surveys, participatory observation, depth interview, and field notes. The data were analyzed using coding method, matrix analysis, event index filling, conceptual-cause formulation, and conclusion validation. To find the sources, the researcher investigated $B B S$ advertisement in the newspaper, internet and informant. The researcher also did interview with wide range of informants, from the officers of BBS to students who use the BBS service. Sampling method in this research used accidental sampling, while conclusion was examined with cross-case and triangulation method. This research finally found that (1) thesis writing supervision in almost all of campuses is not effective and there is no clear scheme of financing in thesis supervision process, (2) BBS service known for its capability, easiness, and guaranty, and by that, BBS service is hugely demanded; (3) the characteristics of BBS service users are: from Jogja region, from private universities, non-engineering program students, participants of regular/ extension/ long distance program, last phase of study (student who stands in semester 6 9 and or will be DO), and students who works/ who are employees.
\end{abstract}

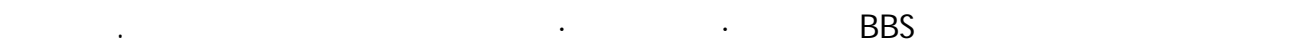

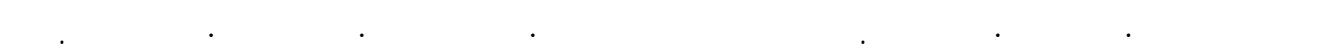 - ter

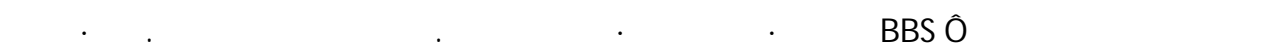

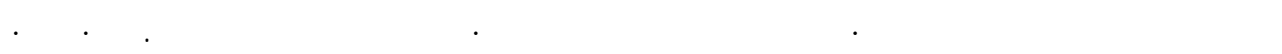

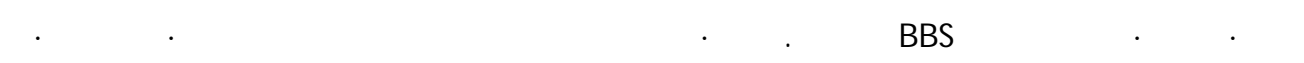 .}

Keywords: thesis, university student, campus, BBS

\section{A. Introduction}

A problem about undergraduate students' thesis writing with the offer from Biro Bimbingan Skripsi (BBS) or thesis writing advice bureau in Yogyakarta is a common problem which is also faced by other educational cities in Indonesia. This research departs from the questions (1) how is the growth of BBS 
background existence outside campus? (2) What are the types of services offered by BBS? (3) From which level do the students who use this service come?

Thesis writing is a prerequisite lecture taken by undergraduate students to gain their undergraduate degree (S1). The measurement of passing this lecture which has 6 credit points (SKS/Sistem Kredit Semester) is decided based on the result of thesis examination. This research shows that thesis is a result of interconnection between state policy, campus culture, and market. Market in this case means "buyer sovereignty" which is outside the state. The obligation of thesis writing, in some circumstances, related to a specific need of the students who become BBS clients. Otherwise, the great number of student population in campuses is the marketing hole.

According to Fuad Hassan (2006), the history of thesis writing could be traced back from university method in Paris in the $12^{\text {th }}$ century. The lecture consisted of studium generale, that was in the morning for lectiones (lectures, lecture given by the lecturers) and in the evening for disputationes (discourses, discussion between lecturers and students). From studium generale emerged a problem that was formulated as questiones (problem that have to be discussed and solved together). To pass the university, students obliged to complete scriptum (thesis, writing). Therefore, university built scriptorium, a special room to write thesis. Studium generale and scriptum built and instituted as movement, identity, tradition and became the essential meaning of campus academic. According to Robert K. Merton, in Ignas Kleden (1987), with that ethos - that were universalism, communality, not looking for the reward, regular skeptics - British in the $17^{\text {th }}$ century became a very fertile area for the growing and development of knowledge.

In the history of tertiary education in Indonesia, the policy of thesis writing changed after the coming out of PP No. 60 in 1999 about tertiary education, especially verse 16 (1): "Final examination of a study program of a degree program may consist of comprehensive examination, or writing work examination, or thesis examination”. This verse replaced verse 16 in PP no. 30 in 1990, which required thesis examination to get university degrees. According to 
de jure, this PP no. 60 in 1999 was not effective because UU no. 2 in 1989 about National Education System referred has been replaced by UU no. 20 in 2003. However, de facto the impact of effectiveness of that PP is regarded as decreasing campus obligation to implement writing thesis service. UU no. 20 in 2003 about National Education System do not require thesis as the only passing requirement to get academic degree, profession or vocation. ${ }^{1}$

As part of academic activities, the working way of students who write thesis is arranged by a set of value system that occurs in the circle of academic society. Beside scientific principles, each university commonly has different characteristic and rule in writing thesis from other universities. This differentiates thesis to other scientific writing such as paper, essay, media opinion, and paper in Journal. Therefore, thesis writing with all of its difficulties must be returned as institutional, social and university campus academic nuance problem.

Moving from the condition above, this research used Cash flow Quadrant theory from Robert T. Kiyosaki (2003) to analyze production pattern of thesis writing that is done by BBS to serve students' demand as service users or clients. This BBS implementation of production pattern is expected to be able to find production pattern of thesis writing. Cash flow Quadrant theory proposes that there are four type of people work (produce), namely type E (Employee), type $S$ (Self-employee), type I (Investor), type B (Business owner). The interrelationship

*The writer is a lecturer in Islamic Education Program in the Faculty of Islamic Science UII. E-mail: hujair@lpm.uii.ac.id

${ }^{1}$ Some Universities do not require thesis as the passing degree requirement. As the alternative is TA (Tugas Akhir/ final assignment), lectures comprehensive examination, or following some lectures based on the educational historical note, by referring to PP no. 30 in 1990 about tertiary education, each University is likely to get different policy based on department/study program proposal. The background of the emerge of that PP was the high number of DO threat because of being late in finishing the thesis. The implementation of PP no. 30 in 1990 creates controversy and invites pro-contra in the campus circle. In UI campus, the Faculty of Art removes thesis in its entire department. The requirement of passing is based on comprehensive examination mark from all lectures orally. In Unhas and ITB, students of exact science write paper after field study. While the students of Art and Designs in ITB are still required to write thesis. Undip requires thesis for its students. USD required thesis to pass, but students do not need to take comprehensive examination. See "Siapa Suka Jadi Sarjana Tanpa Skripsi (Who love to be Bachelors without thesis)" in the magazine of Forum Keadilan 25 may 1995 (On-line) available at http://www.hamline.edu/apakabar/basis data/1995/05/18/0004.html 
between BBS service and students as clients based on the theory of Cashflow Quadrant illustrated in the matrix below:

Matrix 1. four types of thesis production

\begin{tabular}{|c|c|}
\hline $\begin{array}{l}\text { E (Employee) } \\
\text { If BBS works fully, then students } \\
\text { work as thesis writing-aid service } \\
\text { users }\end{array}$ & $\begin{array}{l}\text { B (Business owner) } \\
\text { If BBS has system and people to } \\
\text { help the thesis writing, then } \\
\text { students become partner }\end{array}$ \\
\hline S (Self-employer) & I (Investor) \\
\hline $\begin{array}{l}\text { If BBS does by his own way, then } \\
\text { students work as thesis buyers }\end{array}$ & Money works for students \\
\hline
\end{tabular}

Based on a survey result, most of students utilized production pattern in the left side quadrant, which is type E (Employee) or type S (Self-employee). It means that students write thesis with their own energy, time and fund. While others take the benefit of BBS service out of campus, by choosing left side quadrant, namely type B (Business owner) and type I (Investor). Students of type I tend to require quick thesis writing service and just by paying the approved fund. They complete all of the need during thesis writing by giving entire contract to BBS. While students of type B (Business owner) pay only as much as they need and just need the service that is not available in campus, for example data collection, processor and analysis, and full advising service. For this two of students' types BBS offers its service. The attitude of students in the right quadrant becomes the focus of this research.

This research identified three variable of research namely dependent variable, independent variable and moderating variable. The dependent variable in this research is PBS (thesis supervision demand). PBS is demand patterns that are needed by the service users to BBS and as well as other services that can not be filled by BBS. Independent variable includes KPS (thesis writing need) and LBS (thesis supervision service). KPS is the need required by students during thesis completion, such as financial, permission, research ability, data access and information, and the time of writing. While LBS is the offers form that come from student external - even from thesis advisor or BBS outside campus - such as the composition of proposal, data collection, tabulation and data processor, thesis 
writing consultation, editing and revising. The availability of those services more or less determines the quality of thesis supervision. Whereas moderating variable is LBT (transaction background), such as case uniqueness that affect the occurrence of the transaction between service users with BBS arrangement. Therefore, the occurrence of thesis writing transaction includes students' background and BBS management background.

Methods of data collection is by tracing BBS advertisements in seven newspapers during February - March 2007, consisting of Bernas Jogja (14 Feruary), Kompas Jogja (24 February), Radar Jogja (27 February), Koran Merapi (27 February), Kedaulatan Rakyat (28 February and 1 March), and Seputar Indonesia (28 February). Data were also traced in the internet, especially about pro-contra BBS, blog and mailing-list, and thesis policy and history. This survey stage was very helpful for the next step, remembering that so far there was no authentic data that showed the population of BBS, specifically those who operated in Jogja. Therefore, the researcher used help from informants to expect knowing the early profile of BBS, before later open access communication to BBS.

Later, the researcher did a survey and participatory observation by doing in-depth interview with seven sources of BBS, to discover and figure out service practices which are known as hidden academic phenomena or academic underground. The interviews was unstructured, less interruption, arbitrary, to dig non-standard information, emphasis on the exception, divergence, or uncommon interpretation. Question and answer session flew like daily conversation and it took several weeks. Sample of BBS was taken by accidental sampling. In its progress, there were only seven BBS that succeeded to be examined from ten planned BBS, as shown in the matrix below:

Matrix 2. BBS identities

\begin{tabular}{|l|l|l|l|l|}
\hline & Contacted person & $\begin{array}{l}\text { Position in } \\
\text { BBS }\end{array}$ & Location & $\begin{array}{l}\text { Time of survey } \\
\text { and observation }\end{array}$ \\
\hline BBS1 & Informant 1 & Owner (B) & Sleman & May 2007 \\
\hline BBS2 & Informant 2 & Owner (B) & Yogyakarta & May 2007 \\
\hline BBS3 & Informant 3 & $\begin{array}{l}\text { Data analyst } \\
\text { (E) }\end{array}$ & Sleman & May 2007 \\
\hline BBS4 & Informant 4 & Chief (B) & Yogyakarta & May 2007 \\
\hline
\end{tabular}




\begin{tabular}{|l|l|l|l|l|}
\hline BBS5 & Informant 5 & Owner (B) & Sleman & June 2007 \\
\hline BBS6 & Informant 6 & Owner (B) & Sleman & June 2007 \\
\hline BBS7 & Informant 7 & Chief (B) & Yogyakarta & August 2007 \\
\hline
\end{tabular}

Notes:

(B) : Business owner

(E) : Employee

For data analysis methods, the steps were data codification, matrix arrangement, event index filling, conceptual causal net formula, and conclusion testing. To test the conclusion, inter cases analysis and triangulation were done. Inter case analysis employed by comparing undergraduate thesis with cases of postgraduate thesis and dissertation supervision. While triangulation was done by having a structured interview with 20 informant which consisted of 10 students (5 males and 5 females from 5 state universities and 5 private universities), 5 thesis supervisors (2 males and 3 females from 3 state universities and 2 private universities), and 5 tertiary education executives (4 males and 1 female from 3 state universities and 2 private universities) in Yogyakarta.

\section{B. Discussion}

1. Background of the growth of BBS existence outside the campus

To answer the background of existence growth of BBS outside campus, the researcher analyzed field notes from 7 informants of BBS about campus culture (perception about campus and lecturer bureaucratic), service users' motivation (the need to finish quickly/just finish/qualified), BBS actor characters (idealism/pragmatism/last choice), and external factor of BBS (potential, chance, and management).

The background of existence growth of BBS is moderating variable that shows the background of transaction. This variable elaborates the background of BBS manager, with some unique cases that influence the occurrence of transaction between service user and BBS executives. 
First, about campus culture, the 7 BBS informants did not appreciate in detail. However, one of them questioned about the policy and bureaucratic service to build writing culture in campus as the basic for students to write thesis. Disability and unusual to write in the circle of students were the root of problem with long causes. In his statement, he said that:

But what is not unimportant is that students never been taught how to write when they are in campus, while in the other side thesis writing is required. If it is because of the minimum number of book (library), they can find anywhere. If about the bureaucratic problem, how difficult the bureaucratic is still can be passed. The strict of supervisor, it can be suited to the lecturer's favor. But if they can not write, that must be a real problem $^{2}$.

Second, about motivation of service users, that was the will of students to finish their thesis quickly and easily or qualified and better, all 7 BBS informants answered as less optimality of thesis supervision in campus. This is in contrast with BBS supervision that is deep, even for technique problems. Moreover with the more campus open extension program, with students' type who are economically high, but do not have learning ethos, and only reach for mark and title. Whereas, when students have already got thesis theme and title, BBS will supervise for enriching. In the other hand, if the students have not got it, then BBS will discuss with them for deepening based on the student's interest.

For student with low capability or because of business reason, most BBS appreciated similarly. Low capability was understood as the problem of research methodology mastery, for students or supervisor. While for the anxiety that if students did the thesis by themselves the results would be not optimal, it brought the problem of better finishing. For busy students, the consequence was choosing BBS service. In the statement of informant 6 , he said that:

It can be because of the supervisor, who does not master the methodology, so that once a supervisor refers to other supervisor (who masters the methodology).., or there also is a supervisor who refers to consultant.... In the theory, students may master,...the difficulty is if students have to use journal, whereas te methodology of journal is never been taught in undergraduate level (S1).

\footnotetext{
${ }^{2}$ Based on interview result with informant 5, Sleman, Sunday 10 June 2007
} 
So thesis length factor was the lecturer. The lecturer's demand was too high meanwhile he did not provide enough time. Whereas, students had to not loose time to finish soon. ${ }^{3}$

Third, field note result described the characteristics of BBS actor as the ability to analyze the condition of thesis writing supervision non-optimality in campus as a service opportunity. Minimally, most BBS did not need physical office that representative (some BBS "office" was rented room), did not employ many employees and was not a picture of white collar profession. ${ }^{4}$ The field observation showed that minimum fulfillment of BBS office can optimize the service work.

BBS profession is in meanwhile or part time profession. BBS profession is the expertise of punctuality to prioritize service users based on the service quality and punctuality. BBS actor character is resulted from the relationship between campus and market and capable to become transaction background. Punctuality expertise and completing minimum performance for basic professional need as Kiyosakian's, How to get rich, that is some tips to master four business concepts including debit, credit, asset balance and responsibility.

For example, in the statement of informant 3, BBS actor character was in the position as follows:

We are campus partner; from outside we help some problems which is not or not yet optimal in campus. (I have examined learning supervision for school for a long time, learned pilgrimage (Haji) supervision hold by community because Depag does not appreciate haji candidate as a costumer that has right and obligation). I hope with you that this research can appreciate this business differently, as our conversation on the telephone yesterday. ${ }^{5}$

While informant 6 mentioned as follows:

\footnotetext{
${ }^{3}$ Based on interview result with informant 5, Sleman, Sunday 10 June 2007

${ }^{4}$ Collar profession is the joke of informant 3 via telephone on Saturday 19 May 2007 about BBS self image. In his opinion, the important thing is the ability to complete the client order, especially with first rate service and finishing time limitation. About the appearance of BBS actor, informat 3 requires neat and do not need to wear tie. Wearing tie is high economical status which is not suitable to BBS, because the inforrmat claim that the status of BBS business is UKM (low and middle trade)

${ }^{5}$ Based on interview result with informant 3, Sleman, Friday 11 May 2007
} 
Complete each other. Because there are many supervisors who say to his students "if you have got problems, please contact me"... there had been data processor of Tarbiyah IAIN (read: UIN) students whose supervisor recommended him/her to contact one of lecturer in IKIP (read: UNY) if there was a problem about statistics. Then the lecturer suggested that he/she processed his data in rental computers. If about the theory they have already known but about that problem they do not know. ${ }^{6}$

When giving comment on the routines of thesis writing and the decline of campus learning capacity, for example the informant appreciated many cliche problems. In the informant 7 statement, it was found out:

...say UGM, accepted 40 extension students from Irian, they want to accept. Their promise to pemda (government) is to pass them. Is the human resources can not be passed then how?... if the person is not clever and has Rp.200 millions enter to medical faculty of UII, will he/she be accepted? Then there is someone who has capability, gets achievement and then enters Medical faculty of UII and he/she writes Rp. 1.500 as contribution, will she/he be accepted?

...al long as we still oriented to the profit, what happen is Satan circle. For instance UNY has PPKP, UGM has D3, and then what will the private university get? Finally, who has less money does not need private university, and private university unlikely to not passing the students. There might be no more students register to the university then. ${ }^{7}$

Fourth, about BBS external factor was the continuous functions of BBS with their service. Even there had not rule or service standard yet for its management, BBS has potential and continuous opportunity and became transaction background.

Furthermore, the background of existence growth of BBS is the moderating variable that showed the transaction background. BBS growth existence background was meant to elaborate more the background of BBS managers, with the uniqueness cases that influence the occurrence of transaction between service users and executives.

\section{Forms of BBS service}

\footnotetext{
${ }^{6}$ Based on interview result with informant 6, Sleman, Friday 15 June 2007

${ }^{7}$ Based on interview result with informant 7, Yogyakara, Wednesday 15 August 2007
} 
To answer research question about the forms of BBS service, the researcher analyzed field notes from seven BBS informants on the identity of BBS (individual/team, having office/not, having trade permission/not; main job/part time job, autonomy/ get the job from others, graduated from SLTA/diploma/ not graduated from undergraduate/ undergraduate/post graduate) way of advertising (advertisement/non-advertisement, newspaper/name plate/personal network), contact for users to BBS (telephone/email/SMS/meeting), service time (24 hours/office hours/appointment), time of service per person (limited/unlimited), time of finishing the service (limited/month/semester/unlimited), field work (qualitative/quantitative research, field of science/social/humanity), kind of service (supervision/referencing/data processor/typing/revising/translating), service transaction (written contract/spoken statement), service tariff (determined/undetermined)way of thesis writing (original/adoption/adaptation/imitation), profession risk and guarantee (risks from the service users/campus, refused by campus/total revision/partly revision, service users are troublesome/can not pay/ having problem), business climate (compete with other BBS/ complaint from the users)

BBS service form was moderating variable which showed the background of transaction. This variable was to elaborate BBS executives' background, with the unique cases that affect the occurrence of transaction between service users and BBS executives.

First is about the identity of BBS. The field notes gave description as follows: for BBS who worked alone, if they were having trouble with too many orders beyond their capability, the BBS would contact the network they had. However, most BBS chose to work in team, with different policy inter BBS. With this team model, BBS could be more productive, might keep the quality and more optimal in giving the service.

About the ownership of BBS office with its trade permission, the researcher did re-verification in the field in the form of SIUP (trade permission letter) document and $\mathrm{HO}$ (disturbance permission). The result showed that documents did not refer to BBS trade sector. The SIUP publishing as permission 
service that became the local/district government authority is only mention rental computer business and translation service. It meant that the manager did not register BBS as legal service business, to the Trade and Industry Department or other institution that has the same main duty and function.

All 7 informants agreed that BBS was not main job and did not put it as the only profession. With the background of manager which was undergraduate level (S1), all 7 informants were capable to do all the services. The capability here was understood as service management matters.

Second is about BBS advertising. The most relied method was word by mouth based on friendship network. This way relied on costumer's satisfaction, which depended of first rate service and punctuality. Other ways were by name plate, advertisement, and mass media broadcasting.

Third is about contact of service users with BBS, SMS (short message service) media and telephone that were used to make appointment and meeting schedule. While the process or consultation/supervision was by meeting face to face. The usage of email (electronic mail) as consultation/supervision media was agreed by only one informant, because of the location between BBS and service user.

Forth to sixth, is about time of service. 7 informants of BBS provided optimal time, day or night. While time length for BBS service per person started from 2 hour/meeting to 2-3 meeting/week, and the principle was flexible. For completing service depended on kind and level of thesis difficulty and the activity of the student to consult to the supervisor in campus. 6 informants mentioned the length of time was from one day, one week, and two weeks to 2-3 months, and mostly was less than one semester. The time certainty of completing service was the guarantee, because it related to the fund consequences for the students. Taking long time in writing thesis without time certainty to finish, it meant extending life and study cost, moreover if he/she had got job.

Seventh and eighth, BBS serves all field of study, qualitative or quantitative one and science, social and humanity field of study. The kind of BBS service depends on client need, from title until the last part. Informant 7 states: 
Quantitative and qualitative, fifty-fifty. If for law quantitative is seldom, it must be qualitative. If quantitative is usually for economics department. Now many sospol (social-politic) departments move to qualitative. For example sociology UGM, always rejects quantitative title. ${ }^{8}$

The consequence for BBS is the bank collection of thesis data, from title, abstract, reference, to data processor program refers to latest version. BBS guarantees revision, such as revision problem after thesis examination. In the statement of informant 5 , he/she said:

What is meant by finish here is until accepted revision after examination. It Includes making notes (read: summary) and leads the client to understand the thesis contain. The main thing is that we lead and supervise before stepping forward. ${ }^{9}$

Ninth, all informants did not put the service transaction into difficulty. Service transaction was a written contract/oral statement as agreement symbol between BBS and clients. Service transaction has ever caused bad experience to informant 4, such as:

I had ever written a thesis, when it finished it was not be taken. Then I found out that the student was DO (dropped out). I could not ask for payment because last earthquake his house was broken, then he moved to his family's house in Klaten. ${ }^{10}$

Tenth, is about the service tariff as professional service appreciation accepted by BBS from the service users, it determination referred to type and stage of thesis. As service business, there was no service standard tariff inter BBS, moreover if it related to the service that oriented to the customer's satisfaction. Other consequence from service tariff as contractual relation was the "rational price" choice for the students. The reason is that students have spent lots of money during study, so that it becomes reasonable to pass thesis examination quickly, graduate and get works. If the tariff was put into nominal, for supervision was $\mathrm{Rp}$. 20.000,-/meeting and Rp. 500.000,- to Rp. 2.000.000,- for total service (from title to revision).

\footnotetext{
${ }^{8}$ Based on interview result with informant 7, Yogyakarta, Wednesday 15 August 2007

${ }^{9}$ Based on interview result with informant 5, Sleman, Sunday 10 June 2007

${ }^{10}$ Based on interview result with informant 4, Yogyakarta, Monday 21 May 2007
} 
Eleventh, about the way to write thesis, original writing was the claim from informant 1, 5, and 6; adoption and adaptation relatively done by all informants; and imitation had never been done by BBS. The adoption and adaptation commonly used by changing object, methodology (approach and variable), quotation, bibliography, and research result. Informant 2 and 4 said that field research model was relatively easy to modify. Informant 6 mentioned that there were more statistic technique variations which likely to adapt thesis writing. There was a kind of principle in BBS circle to never break ethic code, scientific or law codes. The minimum limitation of service referred to campus standard and the existence of object and result difference.

Twelfth, about the profession risk and guarantee, all informants acknowledged the success measurement of BBS service was the service user's success in thesis examination, such as the ability to answer questions based on the thesis written by BBS. Commonly students passed with revision, one or two did not pass the exam, hardly ever students passed without revision, and most of them get B (Good) mark. If the thesis is rejected or revised, all informants guaranteed solution. Some informant also approved the service of thesis examination "simulation", namely by discussing materials written and tips to answer the predicted questions, so that the users felt ready to pass through the examination. According to some informants, "simulation" service was proven to be effective for psychological readiness of the users and very tactics to know examiners' attitude and the possible questions.

Thirteenth, 5 informants appreciated the business climate differently. Informant 1 and 5 did not worry and were not in the position of competing with other BBS, informant 3 argued that it was usual to have competition among BBS, while informant 7 felt "competing" with lecturer who made the thesis for the students being supervised.

\section{Characteristics of BBS clients.}

To answer the question about characteristics of BBS service users, the researcher analyzed field notes from 7 BBS informants on sex (male or female), 
client's university (University in DIY/not from DIY; State/ private university; department/or program), and students characteristics (educational background requirement; regular/extension/far distance students; almost DO students; students with low ability; busy students; rich students; lazy students; students with health problem; and students with double study).

Characteristic of BBS service users is moderating variable that describe transaction background. This variable is to elaborate students' background as BBS service users with case uniqueness that affect the occurrence of transaction between service users with BBS manager.

First, about sex, only two informants who gave comment to this question, they were informants 3 and 6 . Informant 3 mentioned more males and in the other hand informant 6 found more female who used their BBS service.

Second, about client hometown and university, informants 1 and 6 only served clients who came from university in Jogja, while other informants also accepted some clients from out of Jogja. Informant 3 served more state university students, while other informants served from private universities. The names of universities mentioned by the informants were Amikom, IST Akprind, STIE YKPN, UAD, UAJ, UGM, UII, UIN Suka, UMY, Unair, UNY, UPN, and UST. The more BBS users from private university were because there were only few state university placed in Jogja. Most informants served more supervision from non technique faculty/ department.

Third, all informant mentioned various characteristic of students who use their service. Most students came from regular, extension and long distance classes. Semester characteristic of clients were semester 6 to 9 or last semester that threatened to be DO (drop out). The users needed quick speed and certainty to pass the university because of cost consideration. Other characteristics were busy and working students.

All informants never served students who were teachers. All informants also never supplied students who had motivation to be the fastest graduation or because they have double study. About the characteristics of students who used BBS service, informant 2 said as follows: 
...students today are stupid, lack of creativity. Yeah, that's it, there are many books which never read. So that work is given to us. They also do not learn to write. Then when they have to write thesis they are confused. Then for those burdens they do not want to lift. ${ }^{11}$

Most informants questioned the policy of extension class whose students were the most BBS users. In the informant 5 statement:

I disagree (extension class) because the orientation is not clear. The campus is only looking for income, students want the title. In the case of knowledge for the students is nothing. Because they are lazy to study,...too old. I often handle extension students, because some of then have no time, are lazy or even unable to think. ${ }^{12}$

\section{Cross case Analysis}

Cross case analysis is a technique to test the conclusion, namely by comparing the answers from three research questions above to thesis or dissertation, in the post-graduate, program writing supervision cases. First, is about the background of BBS existence growth outside campus to cases of thesis writing and postgraduate thesis and or dissertation supervision. This research found a number of certain similarities and emphasis. The lack of thesis supervision optimality in campus was the cause of transaction between students and BBS. The interrelationship between students' need to finish thesis and other assignments, with the variety of reasons and necessity, created the demand. In the marketing system, the existence of demand assumes the connection to order, which in this case was provided by BBS. This transaction, in its development, grew a popular culture in campus that was pro market versus academic culture. The culture was strengthened when students were in the position of sovereignty buyer and BBS optimized the orientation of customer's satisfaction.

If thesis writing was not caused (directly) to the chance to enter working world, or taking post graduate study was a rational determination to delay unemployment as what had become the polemic in the mass media, the completion of undergraduate and post-graduate thesis seems to be whatever and

\footnotetext{
${ }^{11}$ Based on interview result with informant 2, Yogyakarta, Saturday 5 May 2007

${ }^{12}$ Based on interview result with informant 5, Sleman, Sunday 10 June 2007
} 
no quality. Polemic about open unemployment for undergraduate and postgraduate graduations in DIY province presented the following data. According to the Department of Labor and Transmigration, the definition of open unemployment included those who "not working, but is still looking for job" with varied educational background. Unemployed from S1 graduation in DIY increased 146,2\%, from 18,284 people (2003) became 45.020 people (September 2005). While unemployed of S2 graduation is a new trend, the continuity from S1. Besides, job seeker with S1 and S2 education start to be selective and calculative towards working place and salary they get ${ }^{13}$.

Furthermore, the background of BBS existence growth outside campus as transaction background of thesis and/or dissertation writing was a sufficient reason to elaborate the background of BBS appears. The result of inter case analysis about the background of BBS existence growth acknowledges informant data and field notes, that there was increasing of demand to thesis and/or dissertation writing.

Secondly, about forms of BBS service to the case of thesis supervision writing, the researcher also found out some similarity and certain emphasis. The ability to do the service was BBS claim that related to marketing way, field work, and type of service, transaction method, tariff, and competitive business climate. If the need of thesis writing was a chance to develop the service, BBS would provide their capability to offer the need of service users. In the statement of one informant:

${ }^{13}$ For graduation unemployment polemic, see Anonym (2206), S2 Menjadi Ancaman Pengangguran (S2 becomes a threat of unemployment), Jawa Pos, 28 July; Anonym (2006), Sarjana yang Menganggur Terus Bertambah (graduants who are unemployed is increasing continuously), Kompas, 3 May, Anonym (2007), Banyak Lulusan S2 Menganggur: Sulit Klau Hanya Mangandalkan Satu Disiplin Ilmu Saja (Many S2 graduation are unemployed: it is difficult to only depend on one knowledge discipline), Kompas 28 July, Anonym (2007), Lulusan Perguruan Tinggi Masih Kurang Pembekalan (university students are lack of provisioning), Kompas 28 July; Anonym (2207), MAyoritas Mahasiswa Pascasarjana Telah Bekerja (Most postgraduate graduation has worked), Kompas 31 July; Anonym (2007), Pasar Kerja DIY Butuh Tenaga Kerja Siap Pakai (DIY market needs ready to work workers), Kompas, 28 july; Anonym (2007), Sekadar Penghilang Rasa Sakit (Just pain killer), Kedaulatan Rakyat, 6 August; Anonym (2007), Tak Kambing Hitamkan Pendidikan (not to claim education as a scapegoat), Kedaulatan Rakyat, 6 August. 
You may be do not believe, our office is only able to "pass" about 20 theses per year and 20-30\% of it is postgraduate thesis and dissertation ${ }^{14}$.

Other informant also told about thesis writing service forms as follows:

Well since I worked by myself it has been about fifty (undergraduate and postgraduate theses). ... if thesis 3 months, that if I work lazily. ...thesis tariff is bout Rp 3-5 millions depend also on the level of difficulty. ...while for postgraduate thesis, from extension (program) that is mostly old, they are official who study again. There many also are from regular (program), but up until now I have never handled. My friends have ever worked on it $^{15}$.

The service forms of postgraduate thesis and dissertation in compare to undergraduate thesis writing, according to one informant was formulated as follows:

$\mathrm{S} 3$ is different; we lead the student to be how. But S ans S2 are more leading to replication. Modified a little bit. ...yeah. If in UGM there is S2 regular program and one week program, it is treted differently. ...once S2 UGM, the entire thesis was done by me, except for TOEFL because it must be in campus. It means that I have got three $\mathrm{S} 2$ certificate, but I have never go to S2. so if I study there I just need to ask how much is for one semester. Once in one generation, I made 23 (thesis), whereas the number of one generation was only 50 people. There was also S2 class in Solo which consist of 50s, I did 9. So my S2 certificate in Solo is $9^{16}$.

Third, about the characteristics of service users, this research found the interrelationship between students'/users' characteristics with BBS optimal service that tended to strengthen the need and offer for thesis and/or dissertation writing service.

\section{Triangulation result}

Moving from concluding statements that is the answer description of BBS growth background out of campus, forms of BBS services and characteristics of BBS users, the further conclusion testing is by using triangulation technique. Triangulation technique utilized by analyzing results of structured interviews with

\footnotetext{
${ }^{14}$ Based on interview result with informant 3, Sleman, Thursday 10 May 2007

${ }^{15}$ Based on interview result with informant 5, Sleman, Sunday 10 June 2007

${ }^{16}$ Based on interview result with informant 7, Yogyakarta, Wednesday 15 August 2007
} 
20 informants, which consist of 10 students, 5 thesis supervisor, and 5 tertiary educational institution executives.

First, is about the background of BBS growth outside the campus. All 20 informants were asked to comment and elaborate three things, namely thesis writing (difficult-easy; hard-light; enjoyable-not enjoyable), thesis writing result up until now (just like that-varied), thesis writing policy (free-strict; simplecomplicated), campus policy to find funding and /or to connect research funding source for thesis writing (a) often; (b) seldom; (c) never; (d) do not know, acceptation and refusal of the need of thesis supervisor assistant, causes of BBS appear (a) prospective business; (b) limitation of supervision service in campus; (c) rational attitude of the students; and (d) academics permissive.

All 10 students tended to argue that thesis writing as difficult, hard and not enjoyable. In the other hand, all 5 thesis supervisors and all 5 tertiary educational institution executives argued that thesis writing was easy, light and enjoyable. The different characteristics between students and lecturer appealed when they were asked to comment the need of thesis writing assistant, such as agree versus disagree. Students agreed the need of thesis writing assistant because of non optimality of thesis supervision in campus and the necessity to finish the thesis. The elaboration about limitation of thesis supervision in campus was also caused the BBS appear, beside as prospective business. In contrast, tertiary educational executives refused to the need of thesis writing assistant because of campus financial limitation, risky and might cause perception difference and the urgency of thesis supervisor optimality.

All 10 students, all 5 thesis supervisors and all 5 tertiary educational institution executives argued that the result of thesis writing today tended to vary. The same attitude was also stated in the policy of thesis writing that was strict and complicated, there never or seldom was the policy from campus to find research funding for thesis writing, and prospective business and the limitation of supervision in campus was as the cause of BBS to appear.

Research financial source for thesis writing in this case is put in the context of cost scheme policy. Cost scheme policy is financial reachable 
guarantee for students to finish their thesis and study. In the experience of Nanyang Technilogical University (NTU), Singapore - although it is too far and needs some requirements for Indonesia - the policy taken is the patterns of scholarship, official contracts, involved in the research work, and soft loan scheme. As it quoted from a NTU student who comes from Indonesia, it was discovered that:

Later if only we really have a will to study, there are many cost scheme offered by university so that cost is not a big problem. ... A student who is really clever may also get income from doing research projects. Besides, doing research projects is also considered as academic points ${ }^{17}$.

The results of triangulation above show the non optimality of thesis supervision service in campus, as well as in the result of inter campus analysis. Even though there is different attitude between lecturers and students in the case of thesis writing, the policy of thesis writing and the need of thesis writing assistant, both agree to the need of optimal thesis writing supervision by the supervisor in campus. Moreover, all this time campus never or seldom finds donator or offer cost scheme for thesis writing.

Triangulation results also show that optimal fulfillment of thesis writing supervision by the supervisor and cost scheme policy are the alternative to build academic culture in the campus. If this case is less effort by the tertiary educational institution executives, there will be preference of strengthening economic culture pro-market that causes the background of BBS growth outside campus.

Second, about BBS service forms and users characteristics, all 20 students were asked to comment and elaborate the influence of BBS to academic tradition in campus by choosing 4 respond choices, such as: (a) crime; (b) campus need; (c) synergic with academic tradition in campus; (d) do not affect, and attitude to BBS

${ }^{17}$ Anonym, Kuliah di Nanyang: Tak Perlu "Mikir" Biaya (Study in Nanyang University: do not need "think" about the cost), Kompas, 28 January 2006. During 2004 for example, NTU had more than 50 research centres that made about 1,000 basic and advanced research projects by allocating up to 265 million dollar Singapore fund. NTU also cooperates with outstanding tertiary educational institutions in Amerika and Europe. 
also with four respond choices, that are: (a) understandable; (b) questionable; (c) unethical; and (d) academic world threat.

All 10 students, all 5 thesis supervisors and all 5 tertiary educational institution executives tended to consider BBS as academic world threat. And also for the influence of BBS to academic tradition in campus, all 20 informants called it as crime. About BBS as academic world threat, an informant said:

I was called many times by BBS that offer cooperation, in processing the data, analysis and so on. Finally I refused the offer. If the problem is about the limitation of computer, campus laboratory has provided for data processing, analysis and other needs. If the two supervisors are not optimal, students may report this to the campus. This is a fundamental problem in academic culture. The policy I take is the commitment to build attitude and academic value in doing thesis in students circle ${ }^{18}$.

In a different case, another informant said that BBS do not have any effect to campus:

The students' preference to choose thesis is decreasing in compare to final work. The reason is when they are looking for job. Working bureau will not ask about thesis, but visual communication design work made for job seeker. ... and so far I examine, there is not BBS who offer their service to ISI students need. ... the policy here, supervising can be optimal because there is a report form which includes numbers and development process, deadline to finish the thesis, and clear sanction if students do the plagiarism $^{19}$.

While the influence of BBS to academic tradition in campus as a crime, one of BBS informants argue as follow:

Based on the law I dare, because there no rule is broken. Morally, I return $t$ them. ... we remember our responsibility. Scientifically there is ethical code. Try to not break the ethical code, scientific code, or law code. ...

Then, they see the bureau as a plagiarism, whereas we are not plagiarists but consultants. Plagiarism means that I take someone's property,...

However, regulation now has not prohibited what I am doing. If I am invited to discuss with people, why do you establish this bureau, yeah because it is needed by the society, especially student society. If there is someone who comes to study from a distance and he can not (finish)

\footnotetext{
${ }^{18}$ Based on interview result with Ananta Heri pramono, S.E, M.M, as chief assistant I of STIEBANK, in campus, Sleman, Thursday 18 October 2007

${ }^{19}$ Based on interview result with Drs. Lasiman, M.Sn., as chief Visual Communication Design program, Faculty of Art, ISI Yogyakarta in Bantul campus, Friday 19 October 2007
} 
because his lecturer is "killer". If I am asked why am I not asking for permission? If there is permission then I will ask for it. What exists in the regulation is only notary public. And there are two kind of business, and I am not included in that clause ${ }^{20}$.

From the result of triangulation, all 20 informants disagreed to the results of analysis and discussion which talked that BBS is as academic world threat and BBS influence to the campus academic tradition as a crime.

If academic culture is tertiary education identity and matters that threat academic world is a crime, then establishing academic culture is a must that can not be bargained anymore. The first category is self-fulfillment (command), which is if all of academic culture preference is filled. It means that what is nothing yet, unlikely to exist, or even never be in the imagination to exist, but because it has become a policy then there will be an optimal effort to build academic culture. The second category is self-defeating (prohibition), which is a contrast consequence to prove the fault of economic culture or avoiding student assumption as homo economicus or only Kiyokasian with its implementation to all campus life dimensions. Those two absolute must categories oppose academic culture to economic culture that tends to strengthen offer and order of thesis writing supervision service.

\section{Conclusion}

Interrelationship between student clients with BBS as "academic entrepreneurship" shows the existence of the following patterns:

1. Client pattern $(\mathrm{C}, \mathrm{Client})$ that is client as BBS client. BBS work with their own way and their process is not interrupted because the clients have given entire thesis writing. Client's pattern is BBS with S type (Selfemployer).

2. Buyer pattern (B, Buyer), that is client as BBS service buyer. BBS work with full direction based on clients' order. Buyers' pattern is BBS with type E (Employee).

\footnotetext{
${ }^{20}$ Based on interview result with informant 7, Yogyakarta, Wednesday 15 August 2007
} 
3. Partner Pattern (P, Partner), that is BBS clients appreciate BBS service based on their need to finish their thesis. BBS build system, relationship, and access to fulfill the need than can not be done directly by the clients. Partner patter is BBS with B type (Business owner)

Therefore, the high of PBS (thesis supervision demand) influenced by KPS (thesis writing need) and LBS (thesis supervision service). The occurrence of demand is transaction between client's need to BBS service. By making categorization toward other aspects of independent variable that are not prime focuses of this research, such as case uniqueness of students' background and BBS executives' background, the connection between independent variable to dependent variable can be stated in the mathematic formula as follows:

1. if $\mathrm{V} 1<\mathrm{V} 2$, then $\mathrm{V} 4$ tends to support $\mathrm{V} 3$

2. if $\mathrm{V} 1>\mathrm{V} 2$, then $\mathrm{V} 4$ tends to less support $\mathrm{V} 3$

Explanation:

$\mathrm{V} 1$ : thesis writing need

$\mathrm{V} 2$ : thesis supervision service

V3 : thesis supervision demand

V4 : transaction background, including campus tradition, client's motivation,

BBS actor character, and external factors

The formula above can be explained, that, first, if the need of thesis writing is smaller than thesis supervision service, transaction background tends to support the increase of thesis writing demand. Second, if the need of thesis writing is bigger than thesis supervision service, transaction background tends to lessen thesis writing demand.

Based on the research results on the characteristics of BBS clients, a critic is given to Cash flow Quadrant theory of Robert T. Kiyosaki (2003) on his analysis which is individual-behaviorists. It means that production pattern shown by Kiyosaki's theory is more individual and may not be able to catch BBS reality as a social phenomenon. This brings a consequence that the production types may 
not represent working pattern of BBS as an individual business unit. Therefore, this research completes it by the concept of economic culture.

Based on the conclusions above, some suggestions are given as follows:

1. There is a need of strengthening academic culture, writing tradition, and student's involvement in research activity. This is as an alternative for tertiary educational institution executive policy to the growth of BBS outside campus

2. There is a need to optimize strength and remedial functions in the process of thesis writing supervision in campus. This is as an alternative for tertiary educational institution executive policy to BBS service forms which orient at client's satisfactory.

3. There is a need of evaluation and/or closing extension class program. Less optimal of program management and image arrangement of extension program make it becomes the biggest client of BBS service. This is as an alternative for tertiary educational institution executive policy to the characteristics of BBS clients.

\section{BIBLIOGRAPHY}

"Siapa Suka Jadi Sarjana Tanpa Skripsi," Majalah Forum Keadilan 25 Mei 1995 (On-line) on http://www.hamline.edu/apakabar/basisdata/1995/05/18/ 0004.html

Anonym. 2006. "Kuliah di Nanyang: Tak Perlu 'Mikir' Biaya" in Kompas, 28 January.

Anonym. 2006. "S2 Jadi Ancaman Pengangguran” in Jawa Pos, 28 July.

Anonym. 2006. "Sarjana yang Menganggur Terus Bertambah" in Kompas, 3 May.

Anonym. 2007. "Banyak Lulusan S2 Menganggur: Sulit kalau Hanya Mengandalkan Satu Disiplin Ilmu Saja" in Kompas, 28 July.

Anonym. 2007. "Lulusan Perguruan Tinggi Masih Kurang Pembekalan" in Kompas, 28 July.

Anonym. 2007. "Mayoritas Mahasiswa Pascasarjana Telah Bekerja" in Kompas, 31 July.

Anonym. 2007. "Pasar Kerja DIY Butuh Tenaga Siap Pakai” in Kompas, 28 July. 
Anonym. 2007. "Sekadar Penghilang Rasa Sakit" in Kedaulatan Rakyat, 6 August.

Anonym. 2007. “Tak Kambinghitamkan Pendidikan” in Kedaulatan Rakyat, 6 August.

Fuad Hassan. 2007. "Catatan Perihal Pendidikan Tinggi" on http://www.ui.edu. accessed on 14 August 2007.

Kleden, Ignas.1987. Sikap Ilmiah dan Kritik Kebudayaan. Jakarta: LP3ES.

Kiyosaki, Robert T. \& Sharon L.Lechter C.P.A. 2003. The Cashflow Quadrant: Panduan Ayah Kaya Menuju Kebebasan Finansial. Jakarta: Gramedia. 